\title{
Comparative Analysis of in Vitro Antioxidant and Cytotoxic Activity of Unripe and Ripe Fruits of Solanum sisymbriifolium
}

\author{
Farhana Momen ${ }^{1}$, Rashu Barua ${ }^{1,2}$, Md. Golam Kabir ${ }^{1 *}$ \\ ${ }^{1}$ Department of Biochemistry and Molecular Biology, University of Chittagong \\ Chittagong-4331, Bangladesh. \\ ${ }^{2}$ Department of Molecular Biochemistry, Nagoya University Graduate School of Medicine \\ Nagoya-466-0065, Japan \\ ${ }^{*}$ Corresponding author's email: Kabir [AT] cu.ac.bd
}

\begin{abstract}
Solanum sisymbriifolium Lam. (Solanaceae), commonly referredto as Kantikari (Bengali), sticky nightshade, or litchi tomato. Despite, the traditional use of this plant for several ailments, very little is $k$ no wn about the phytochemical and pharmacological content of the edible ripe berries of this medicinal plant. Ethanol and petroleum ether extract of the ripe and unripe fruits of Solanum sisymbrïfolium were examined by using stand ard analytical methods to determine and compare their bioactive chemical constituents, total phenolic content, antioxidant, and cytotoxic potential. Quantitative phytochemical screening showed that the presence of medicinally active secondary metabolites like alkaloids, flavonoids, and saponins were detected in both ripe and unripe fruits. Antioxidant activity and total phenolic content were found to be more pronounced in ripe fruit extract, whereas unripe fruit extracts showed moderate cytotoxic activity. DPPH free radical scavenging method demonstrated that I $C_{50}$ value of ethanol and petroleum ether extract of ripe fruits were $194.40 \mu \mathrm{g} / \mathrm{ml} \mathrm{and} 436 \mu \mathrm{g} / \mathrm{ml}$, and for unripe fruit the values were $689.82 \mu \mathrm{g} / \mathrm{ml}$ and $1411.23 \mu \mathrm{g} / \mathrm{ml}$. In brine shrimp lethality bioassay, the $\mathrm{LC}_{50}$ value of unripe fruits was $230.6559 \mu \mathrm{g} / \mathrm{ml}$ for ethanolextract and $314.9227 \mu \mathrm{g} / \mathrm{ml}$ for petroleum ether extract. The $L C_{50}$ value of the ethanol extract of ripe fruits was $456.1021 \mu \mathrm{g} / \mathrm{ml}$ and for petroleum ether extract was $1,017.6848 \mu \mathrm{g} / \mathrm{ml}$. The results of this study showed that the litchitomato not only has the potential to be a rich source of an edible compound due to the presence of profound phytochemical constituents but also can be used as a source of pharmacological references.
\end{abstract}

Keywords - Solanum sisymbriifolium, Phenolic content, Antioxidant, Cytotoxicity.

\section{INTRODUCTION}

The popularity of medicinal plants as relief fromnumerous illnes ses is rapidly increasing across the world despite the immense advancement of conventional chemicaldrugs. Countless side effects are often encountered with these drugs while treating and managing diseases, whereas medicinal herbs and natural products can bec ome a source of hope to meet the healthcare needs due to the lower side effects in comparison to the prescription drugs. In today's world, soaring concern exists over the escalation in oxidative stress-related disorders such as cancer, cardiovascular disease, Alzheimer's, autoimmune dis ease, atherosclerosis, diabetes, multiple sclerosis ${ }^{[1]}$. When free radicals with an un paired electron overwhelm the antioxidant protective sy stem, a condition known as oxidation stress develops which leads to the disintegration of cell membranes and cellcompounds including proteins, lipids, and nucleic acids ${ }^{[2]}$. It results from the imbalance between the productions of free radicles (reactive oxygen and nitrogen species) and the antio xid ant defen se system. Numerous studies with plant phytochemicals showed that the phytochemicals with antioxidant activity help s in converting the free radicals to less reactive species ${ }^{[3]}{ }^{[4]}$. Many researches have been focused on abilities of different plants to induce antioxidant effects due to the concerns about the safety of synthetic antioxidants. Various plant extracts contain antioxidant compounds that protect cells against the damaging effects of reactive oxygen species (ROS), such as peroxides, superoxide, hydroxyl radical, singlet oxygen, and alpha-oxygen ${ }^{[5]}$. Several studies have sho wn the inverse relationship between a human diet containing antioxidant-rich food and the incidence of human diseases ${ }^{[6], ~[7]}$.

Researches on the screening of extracts and is olated constituents of medicinal plants used traditionally to treat cancer has intensified intending to find out potential cy totoxicity for cancer chemotherapy ${ }^{[8], ~[9] . ~ P r o p e r ~ s ~ c i e n t i f i c ~ e v ~ a l u ~ a t i o n ~ o f ~}$ many traditionally used plants in Bangladesh for the cytotoxic effect would carry enormous potential and promise as part of pharmaceutical products ${ }^{[10]}$. 
Since ancient times both cultivated and wild species of the Solanaceae family have played an es se ntial role in human nutrition and health ${ }^{[11]}$. Nevertheless, there are wild species with the great significance of this family that has not been reported much on their pharmacological activities. Solanum sisymbriifolium (LitchiTomato) is one of the wild plants which is a viscid and very prickly erect spiny shrub commonly known as Kantikari (Bengali), Kanta begun, Sticky nightshade (English). It originates in South America, where it is used for cooking and medicinal purposes. It is commonly found throughout Bangladesh. This plant has been used as a trap crop for the management of potato cyst nematode $(\mathrm{PCN})^{[12]}$. The chemical constituents previously reported being found in the roots of S. sisymbriifolium were cuscohygrine and solacaproine ${ }^{[13]}$. Solas odine (molecular formula: $\mathrm{C} 27 \mathrm{H} 43 \mathrm{NO} 2$ ), a glycoalkaloid used in the sy nthesis of corticosteroids, sexhormones, and a large component of oral contraceptives, has been is olated from this plant ${ }^{[14]}$. The edible fruits are globose-ovoid and shiny red when ripe, and comparable to cherries and gooseberries in tas te. The berries contain sisymbriifolin (a neolignan) and carpesterol (a rare C30 sterol) ${ }^{[15]}$. Traditionally the root of the plant has been us ed in indigenous medicine for the treatment of hypertension, hy steria, diarrhea, res piratory tract infections, and various central nervous system(CNS) dis orders such as epilepsy and depression ${ }^{[16]}$. These activities of Solanum sisymbriifolium may be due to the presence of a diversified groups of phytochemicals and compounds, and many of which possess antioxidant and cytotoxic activity. As we know, fruits synthesize a wide array of phy tochemicals at differe nt ripening stages that are reported to havehealth-promoting effects in humans. Therefore, to establish its traditional u ses, the present investigations were carried out to study and compare the phy tochemical screening and pharmacological activities of ethanol and pet ether extract fromboth ripe and unripe fruits of S. sisymbriifolium available in Bangladesh.

\section{MATERIALS AND METHODS}

\subsection{Sample Collection and Extraction:}

The fresh unripe and ripe fruits of Solanum sisymbriifolium were collected from the hilly areas of Khulsi, Chittagong, a dis trict of Bangladesh. The study was carried out in the Department of Biochemistry and Molecular Biology, and the species was identified by Dr. Sheikh Bokhtear Uddin, Professor, Department of Botany. The collected fruits were washed and sun-dried for consecutive days. The dried unripe and ripe fruits were ground to a coarse powder with mort ar and pestle separately. The dried powder of unripe and ripe fruits was macerated in ethanol and pet ether in a separate conical flask for 5 days at room temperature $(25 \pm 1)^{0} \mathrm{C}$ with occas ional stirring. After completion of the extraction, the liquid was filtered us ing a sterilized Whatman No.1 filter paper. Then the filtrate was concentrated under reduced pre ssure be low $50^{\circ} \mathrm{C}$ through a cy clone rotary evaporator (RE200, Bibby sterling, UK). The concentrated extracts were collected in a petri dish for complete evaporation of ethanol and pet ether. The whole process was repeated three times and fin ally, 15 gm Green-colored concentrated plant extracts of unripe fruits and $15 \mathrm{gm}$ red-colored plant extract of ripe fruits were obtained (yield $2.22 \% \mathrm{w} / \mathrm{w}$ ). The green and red-colored crude extracts were preserved in the refrigerator at $4^{0} \mathrm{C}$.

\subsection{In Vitro Assay of Antioxidant Activity of Ethanol and Pet ether Extract of Unripe and Ripe Fruits of Solanum sisymbriifolium:}

The antioxidant activity of ethanol and pet ether extract fromunripe and ripe fruits of Solanum sisymbriifolium and the standard antioxidant ascorbic acid were as sessed based on the free radical scavenging effect of the stab le 2, 2- diph en yl1- picrylhydrazyl(DPPH)-free radical activity according to the method described by ${ }^{[17]}$. Briefly, Ascorbic acid and the ethanol and pet ether extracts $(20,40,60,80,100,200,400$, and $800 \mathrm{mg} / \mathrm{ml})$ of ripe and unripe fruits of Solanum sisymbriifolium were prepared in methanol. DPPH (Sigma, USA) solutions $(0.004 \%)$ were prepared in methanol and $5 \mathrm{ml}$ of this was mixed with the same volume of extracts and positivecontrol solution separately. These s olu tion mixt u res were kept in dark for $30 \mathrm{~min}$ and the absorbance of the mixture was determined at $517 \mathrm{~nm}$ using UV-Visible Spectrophotometer (UV-1601 Shimadzu, Japan). Ascorbic acid was acted as a positive control and low absorbance of the reaction mixture indicated higher free radical-s cavenging activity. The scavenging activity against DPPH was calculated using the following equation:

Scavenging activity $(\%)=[(\mathrm{A}-\mathrm{B}) / \mathrm{A}] \mathrm{x} 100$, Here, $A$ is the absorbance of the (DPPH solution without the sample), $B$ is the abs orbance of DPPH solution in the presence of the sample (extract/ ascorbic acid).

Then, $\%$ s cavenging activity or \% inhibition was plotted ag ainst log concentration and $\mathrm{IC}_{50}$ (Inhibition co nce ntra tion 50) was calculated from the graph by linear regression analysis with Microsoft Office Excel 2007.

\subsection{In Vitro Assay of Cytotoxicity of Solanum sisym briifolium Unripe and Ripe Fruits:}

Cytotoxic activity of ethanol and pet ether extract from Solanum sisymbriffolium were determined by Brine-Shrimp Lethality Bioas say as described by ${ }^{[17]}$. Cys ts (eggs) of Brine shrimp were collected fromthe Institute of MarineScie n ce and Fis heries, University of Chittagong, Bangladesh, and the test samples of ethanol and pet ether extract with differen $t$ concentrations $(20,40,60,80100,200,400,600,800$ and $1000 \mu \mathrm{g} / \mathrm{ml}$ ) were prepared by dis solving them in DMSO (n o more than $50 \mu \mathrm{l}$ in $5 \mathrm{ml}$ solution) along with seawater. A vial of $30 \mu 1 \mathrm{DMSO}$ (Sigma, USA) was used as negativecont rol and standard gallic acid (Sigma, USA) was us ed as a positive control. In each experimental and control vial, 10 Nauplius 
were transferred with Pasteur pipette and were tes ted in triplicate. The test tubes were maintained under illu min ation . After 24 hours have elapsed, survivors were counted with the aid of a 3x magnifying glass. The LC $\mathrm{C}_{50}$ values were calculated fromProbit Chart us ing computer software "BioStat-2009".

\subsection{Phytochemical Screening:}

Phytochemical study was performed through conducting preliminary phytochemical group tests using unripe and ripe fruits of $S$. sisymbriifolium. The presence of alkaloids, flavonoids, and saponins was carried out according to the methods of Harbone (1973) as described by Edeoga et al. (2005), Boham, and kocipaiabyazan(1994) and Ob ad oni and Ocuko (2001) respectively. ${ }^{[18][19][20][21]}$

\subsection{Total Phenolic Content Determination:}

Total phenolic content (TPC) of the ripe and unripe fruits of Solanum sisymbriifolium was determined by FolinCiocalteu reagent (FCR) ${ }^{[22]}$. Briefly, $5 \mathrm{ml}$ freshly prepared dilute Folin-Ciocalteu Reagent and $4 \mathrm{ml}$ of $7.5 \%$ sodium carbonate were added to $1 \mathrm{ml}$ of dilute plant extract $(200 \mathrm{mg} / \mathrm{ml})$ to prepare the reaction mixture. Thes e mixt u res were kept in dark for $1 \mathrm{~h}$ at ambient conditions to complete the reaction. The absorbance was measured by using a spectrophotometer (Shimadzu UV PC-1600) at $765 \mathrm{~nm}$. For standard reference, gallic acid was used and the results were presented as dry weight basis with $\mu \mathrm{g}$ gallic acid equivalent (GAE)/mg of s ample.

\subsection{Qualitative Phytochemical screening}

\section{RESULT}

The phy tochemical screening was carried out to analy ze the presence of alkaloids, flavonoids, and saponins in both the ripe and unripe fruits of Solanum sisymbriifolium. Although, the mentioned phytochemical characters we re pre se nt in both ripe and unripe fruits, the investigation revealed that unripe fruits are a rich source of alkaloids and saponins, whereas flavonoids is predominantly present in Ripe fruits (Table 1).

Table 1: Phy tochemical Screening of unripe and ripe fruits of Solanum sisymbriifolium

\begin{tabular}{|l|l|c|c|}
\hline Sl.No. & \multirow{2}{*}{ Phytochemicals } & \multicolumn{2}{|c|}{ Solanum sisymbriffolium } \\
\cline { 3 - 4 } & & Unripe Fruits & Ripe Fruits \\
\hline 1. & Alkaloids & ++ & + \\
\hline 2. & Flavonoids & + & ++ \\
\hline 3. & Saponins & ++ & + \\
\hline
\end{tabular}

\subsection{Total Phenolic Content}

Total phenolic content (TPC) of the fruit extracts were determined according to the method described by FolinCiocalteu reagent (FCR), expressed as Gallic acid equivalent phenol compounds and was reported as Gallic acid equivalents $(\mathrm{GAE})$ by reference to a standard curve $(\mathrm{y}=0.013 \mathrm{x}+0.106 ; \mathrm{r} 2=0.998)$ (data not shown). Ethan ol and pet ether extracts of ripe fruits showed higher TPC content which were 62.15 and $57.83 \mu \mathrm{g}$ GAE/mg of dry weight compared to the ethanol and pet ether extracts of unripe fruits which was 48.75 and $46.28 \mu \mathrm{g} \mathrm{GAE} / \mathrm{mg}$ of dry weight, respectively (table 2).

Table 2: Total phenolic content of ethanoland pet ether extracts of unripe and ripe fruits of Solanum sisymbriifolium

\begin{tabular}{|c|c|}
\hline Name of samples & $\begin{array}{c}\text { Total phenolic content } \\
(\mu \mathrm{g} / \mathrm{gmequivalent} \text { of Gallic acid) }\end{array}$ \\
\hline $\begin{array}{l}\text { Ethanol extract of unripe fruits of Solanum } \\
\text { sisymbriffolium }\end{array}$ & $48.75 \pm 0.30$ \\
\hline $\begin{array}{l}\text { Ethanol extract of ripe fruits of Solanum } \\
\text { sisymbriifolium }\end{array}$ & $62.15 \pm 0.31$ \\
\hline $\begin{array}{l}\text { Pet ether extract of unripe fruits of Solanum } \\
\text { sisymbriifolium }\end{array}$ & $46.28 \pm 0.50$ \\
\hline $\begin{array}{l}\text { Pet ether extract of ripe fruits of Solanum } \\
\text { sisymbriifolium }\end{array}$ & $57.83 \pm 0.26$ \\
\hline
\end{tabular}

Values are means $(n=3) \pm$ SD. Here, all the values are statistically significant at the $5 \%$ level.

\subsection{In vitro Assay of Antioxidant Activity}

A widely used in-vitro mechanis mfor screening the antioxidant activity of plant extract is DPPH radical scavenging due to their hydrogen donating ability ${ }^{[23]}$. In this as say, the violet/purple-coloredDPPH s olution was reduced to the yellow-colored stable diamagnetic molecule, diphenylpicryl hydrazine, by the addition of an antioxidant co mp ound [24] [25]. 
Here, the DPPH scavenging effect of the ripe and unripe fruit extract was compared with ascorbic acid as a s tandard antioxidant. Both the ethanol and pet ether extract of ripe and unripe fruits of Solanum sisymbriifolium have shown dosedependent activity in comparison with Ascorbic acid reference. The antioxidant activity of the fruit extracts was measured by the decrease of absorbance at $520 \mathrm{~nm}$. The increased concentration of both the fruit extracts and the standard showed an increase in antioxidant activity by decreasing the free radicals in the mixture ${ }^{[26]}$.

Eight different concentrations were used in this study and at concentration of $800 \mu \mathrm{g} / \mathrm{mL}$, the value for ripe fru it's ethanol extract amounted to $74.13 \%$, while a similar concentration of green unripe fruit ethanol extract showed a far lower antioxidant activity (53.47\%) (Fig 1). As DPPH scavenging activity \%), fully mature ripe fruit's pet ether extract's activity $(60.59 \%)$ was greater than unripe green fruits pet ether extract's $(47.57 \%)$ (Fig 1$)$. The IC $_{50}$ value of ethanol extract of ripe fruits, ethanol extract of unripe fruits, Pet ether extract of ripe fruits, Pet ether extract of unripe fruits, and Ascorbic acid were found $194.40 \mu \mathrm{g} / \mathrm{ml}, 689.82 \mu \mathrm{g} / \mathrm{ml}, 436 \mu \mathrm{g} / \mathrm{ml}, 1411.23 \mu \mathrm{g} / \mathrm{ml}$, and $1.13 \mu \mathrm{g} / \mathrm{ml}$ respectively (Supplement table 1).

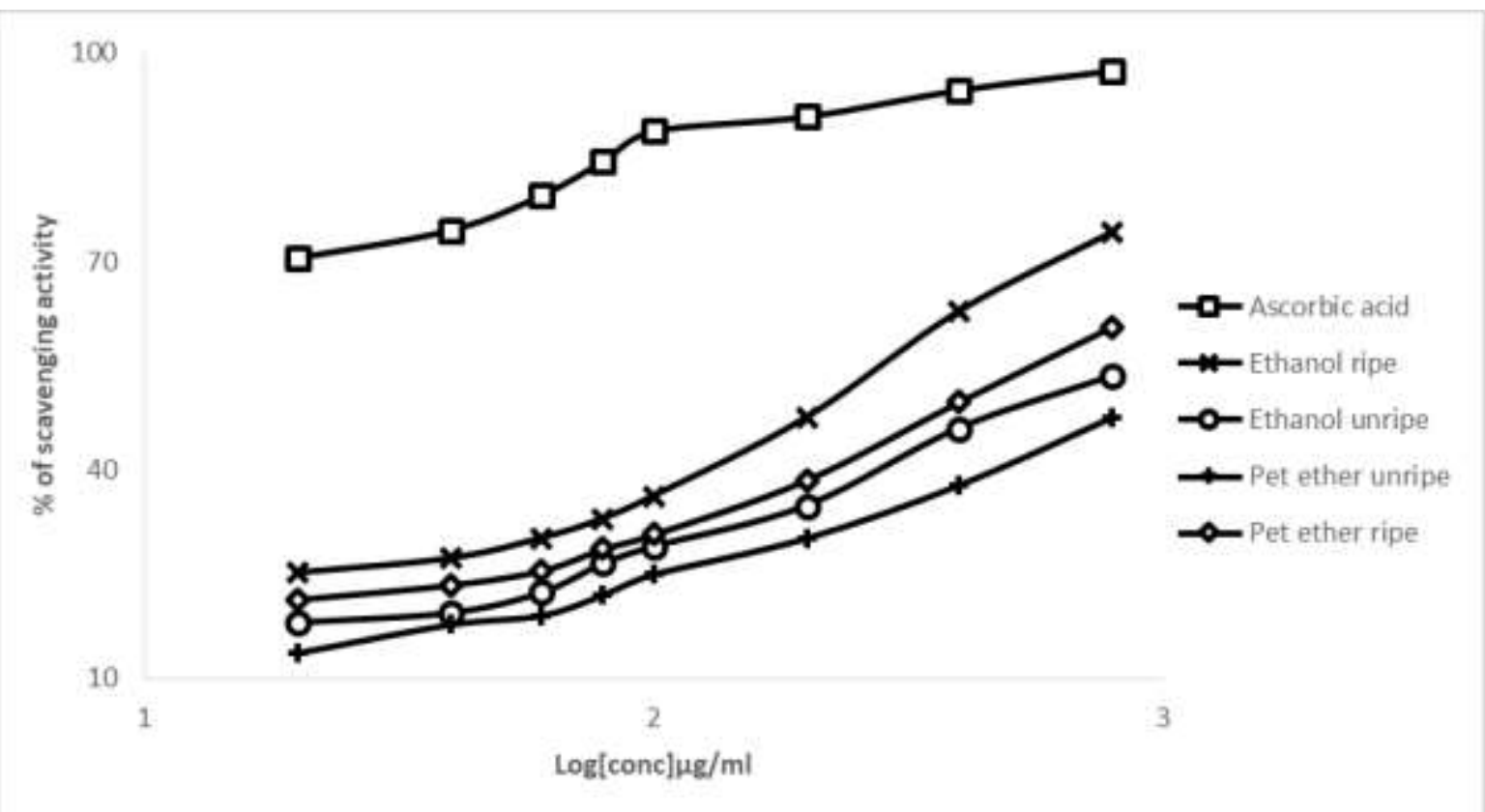

Fig. 1: Comparative \% of scavenging activities Ethanol ripe ( $\left.\mathrm{IC}_{50} 194.40 \mu \mathrm{g} / \mathrm{ml}\right)$, Ethanol unripe $\left(\mathrm{IC}_{50} 689.82 \mu \mathrm{g} / \mathrm{ml}\right)$, Pet ether ripe ( $\left(\mathrm{IC}_{50} 436 \mu \mathrm{g} / \mathrm{ml}\right)$, Pet ether unripe ( $\left.\mathrm{IC}_{50} 1411.23 \mu \mathrm{g} / \mathrm{ml}\right)$ and $\mathrm{Ascorbic}$ acid $\left(\mathrm{IC}_{50} 1.13 \mu \mathrm{g} / \mathrm{ml}\right)$

\subsection{In vitro Assay of Cytotoxic Activity:}

Cytotoxic activity of ethanol and pet ether extracts of unripe and ripe fruits of Solanum sisymbriifolium was as sessed us ing the Brine Shrimp Lethality Bioas say. The results showed that percentage lethality of brine shrimp at ten different concentrations (20 to $1000 \mu \mathrm{g} / \mathrm{ml}$ ) of ethanol and petether extracts of unripe and ripe fruits exhibited lethality in a d o s edependent manner. Ethanol extract of unripe fruits showed 0,10,20,20,30,40,50,80,80 and 100\% mortality of brine shrimp at 20,40,60, 80 100, 200, 400,600, 800 and $1000 \mu \mathrm{g} / \mathrm{ml}$ concentrations (Fig 2), respectively. The LC 50 value of ethan ol extract of unripe fruits was found $230.6559 \mu \mathrm{g} / \mathrm{ml}$, with $95 \%$ confidence limit where the lower and upper limit s were 158.2663 and $346.7523 \mu \mathrm{g} / \mathrm{ml}$ (Supplement table 2). However, pet ether extract of unripe fruits showed $0,10,10,10,20,40,50,70,70$ and $90 \%$ mortality of brine shrimp at 20,40,60, $80100,200,400,600,800$ and $1000 \mu \mathrm{g} / \mathrm{ml}$ concentrations, respectively (Fig 2). The corres ponding $\mathrm{LC}_{50}$ value was found $314.9227 \mu \mathrm{g} / \mathrm{ml}$ (Supplement table 2), with $95 \%$ confidence limit where the lower and upper limits were 214.8288 and $496.0832 \mu \mathrm{g} / \mathrm{ml}$.

Ethanolextract of ripe fruits showed $0,0,10,10,20,20,40,50,70$ and $80 \%$ mortality of brine shrimp at 20, 40, 60, 80100 , 200, 400,600, 800 and $1000 \mu \mathrm{g} / \mathrm{ml}$ concentrations (Fig 2), respectively. The $\mathrm{LC}_{50}$ value of this extract was found $456.1021 \mu \mathrm{g} / \mathrm{ml}$ (Supplement Table. 2), with 95\% confidence limit where the lower and upper limits were 306.8122 and $783.8993 \mu \mathrm{g} / \mathrm{ml}$. Pet ether extract of ripe fruits showed 0,0,10,10,10,20,30,40,40 and 50\% mortality of brine shrimp at 20, 40, 60, $80100,200,400,600,800$ and $1000 \mu \mathrm{g} / \mathrm{ml}$ concentrations (Fig 2), respectively and the $\mathrm{LC}_{50}$ value of the corresponding extract was found 1,017.6848 $\mu \mathrm{g} / \mathrm{ml}$ (Supplement Table. 1), with 95\% confidence limit where the lo wer and upper limits were 543.9804 and $4,319.4246 \mu \mathrm{g} / \mathrm{ml}$.

The $\mathrm{LC}_{50}$ value of Gallic acid was found $4.40 \mu \mathrm{g} / \mathrm{ml}$ (Supplement Table. 1) with $95 \%$ confidence limit where the lower and upper limits were 0 and $10.331 \mu \mathrm{g} / \mathrm{ml}$. 


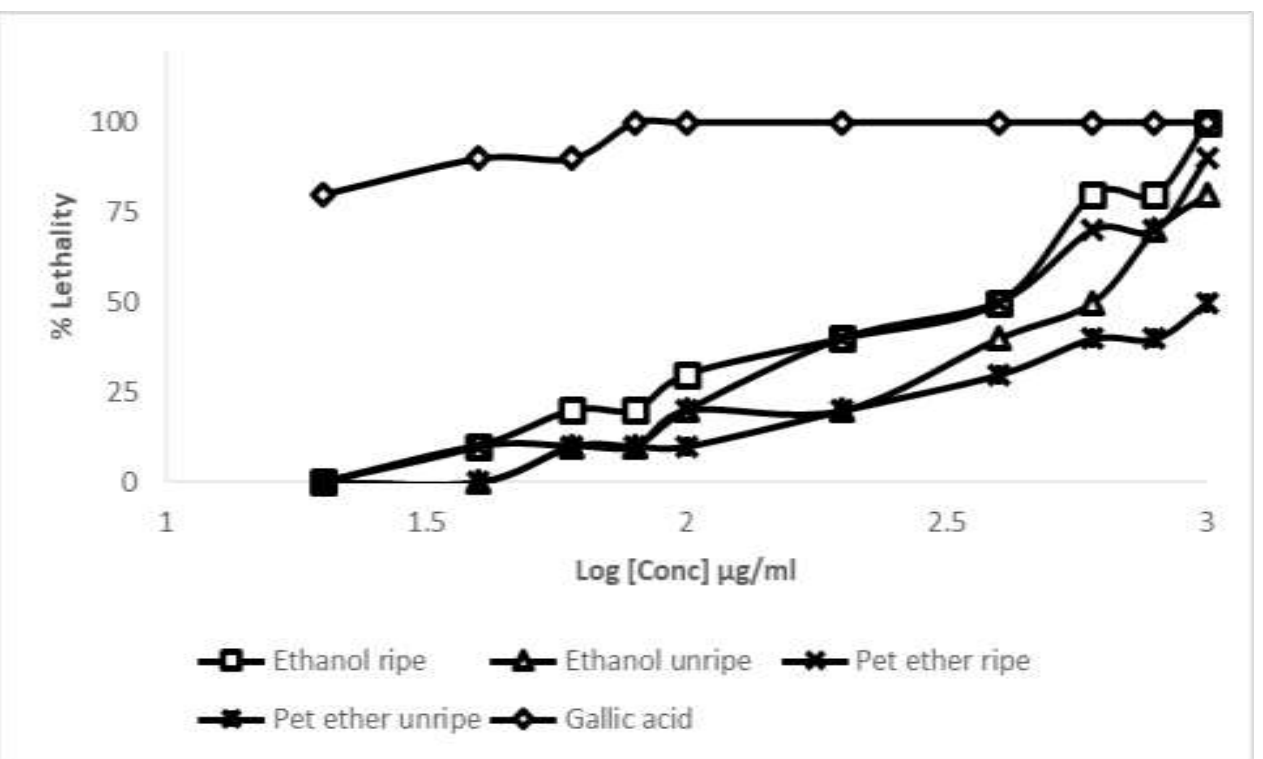

Fig. 2: Comparative \% of lethality ethanol and Pet ether extract of unripe and ripe fruits of Solanum sisymbriifolium with Gallic acid (positive control)

\section{DISCUSSION}

\subsection{Phytochemical Screening}

The phy tochemical screening revealed the presence of medicinally active constituents', alka loids, flavonoids, and saponins in both ripe and unripe fruits of Solanum sisymbriifolium. These findings are in correlation with the pre vio us phy tochemical screening of the extracts which showed that Solanum sisymbriifolium possess alkaloids, fla vo noids, saponins, and other secondary metabolites ${ }^{[27]}$. These secondary metabolites are accountable to produce definite pharmacological actions in the human body which can lead to the development of novel and safe medicinal agents ${ }^{[28] ~[29]}$.

\subsection{Total Phenolic Content}

The current study assessed the Total Phenolic Content (TPC) in the extract of ethanol and petether of unripe and ripe fruits of S. sisymbriifolium. Results showed that ethanol extract of ripe fruits contained higher phenolic content $(62.15 \mu \mathrm{g}$ $\mathrm{GAE} / \mathrm{mg}$ ) than the unripe extracts and the TPC value of pet ether extracts of matured red fruit s was in close proximity of its ethanol extract ( $57.83 \mu \mathrm{g} \mathrm{GAE} / \mathrm{mg})$. Phenolic is a large class of chemical compounds, and in plants, they exist as secondary metabolites ${ }^{[30]}$. These are produced in plant cells through secondary metabolismand function in plant reproduction and growth, and had substantial health potential area of research and medical use ${ }^{[31]}$. Total phenolic content of plant extract is determined as an approach to get the quantitative data for compounds that have the antioxidant potential. Therefore, the nutritional and medicinal value of phenolic compounds provides enormous health ben efits and serves as defense mechanisms to counteractreactive oxy gen species (ROS) ${ }^{[32]}$.

\subsection{Antioxidant Activity:}

Natural phenolic compounds such as flavonoids haveredoxproperties that allow them to act as reducing ag ents and thus, show antioxidant property. In addition, they have the potential to metallic chelating ${ }^{[33]}$. ${ }^{3 h e} \mathrm{IC}_{50}$ value obtained for ethanol and petether fruit extracts and the standard reference ascorbic acid indicate that the efficacy of both the fru its extracts is lower than the ascorbic acid. Researchers have shown that plants synthesize variou s kinds of se condary metabolites that act as antioxidants to thrivein hostile conditions situations ${ }^{[34]}{ }^{[35]}{ }^{[36]}$. The present study reveals that the ripe fruits of S. sisymbriifolium possess greater antioxidant activity compared to the activity exhibited by the fruits immature green stage which may be due to the presence of higher polyphenols and flavonoids in the ripened fruits extracts ${ }^{[37]}$. This phenomenon can be explained by the existence of higher concentration of flavonoids (demonstrated by the phy tochemical screening) in ripe fruits of S. sisymbriifolium compare to the unripe one. Several studies have pro ved that, flavonoids, present in fruits and vegetables are one of the major groups where the free radical scavenging activity is attributed by a broad spectrum of biological activities and are responsible for diminishing free radicals and lipid peroxidation ${ }^{[38]}[39]$. 


\subsection{Cytotoxic Activity:}

Ethanol and pet ether extract of unripe fruits has shown moderate cytotoxic activity compare d to the res pective ripe fruits extract, in comparis on with the positive control (Gallic acid). This result indicates that the fruits of Solanum sisymbriifolium in the immature developmental stage possess a higher amount of potent bioactive compounds, whic $\mathrm{h}$ might be useful as anticancer, antitumor, antimicrobial, and other pharmacological activities ${ }^{[40]}$. Thus, the unripe fru it extracts might be considered for therapeutic and clinical potentials for the treatment of many life-thre atening diseases such as cancer ${ }^{[41]}$. The predominant presence of alkaloids and saponins in unripe fruits could be responsible for the observed bioactivity. Further investigations of the active principles reside in the unripe fruits of Solanum sisymbriifolium are necessary as a varied array of pharmacological activities are indicated by the potent cytotoxic activity of plant extracts.

\section{CONCLUSION}

On the basis of our research results, it can be stated that the unripe fruits extract of Solanum sisymbriifolium demons trated a moderate level of phenolic content and free radicalscavenging activity but showed potent cy totoxic effects, whereas ripe fruits exhibited reasonable cytotoxic effect with higher total phenolic content and greater values of antioxidant activity. Therefore, the ripe fruits of Solanum sisymbriifolium have a significant potential to use as a natural antioxidant agent and to include in food systems to maintain food quality. Furthermore, the demonstrated cy totoxic effects of the unripe green fruits might be subjected to clinical and therapeutic trials for life-threatening dis eases such as cancer. However, further studies are required to explicate detail medicinal values of fruits of Solanum sisymbriifolium for pos sible therapeutic utilization.

\section{CONFLICT OF INTEREST}

The authors declared no conflict of interest.

\section{FINANCIAL SUPPORT}

No funding was received for the study.

\section{ACKNOWLEDGEMENT}

Authors are thankfulto Dr. Sheikh Bokhtear Uddin, Professor, Department of Botany, University of Chittag ong for identifying the plant.

\section{REFERENCES}

1. Valko, M., Leibfritz, D., Moncol, J., Cronin, M. T., Mazur, M., \& Telser, J. Free radicals and antioxidants in normal physiological functions and human disease. The international journal of biochemistry \& cell biology; 39(1): 44-84, 2007.

2. Rahman, K. Studies on free radicals, antioxidants, and co-factors. Clinical interventions in aging, 2(2): 219 . 2007.

3. Barros, L., Cabrita, L., Boas, M. V., Carvalho, A. M., \& Ferreira, I. C. Chemical, biochemical and electrochemical assays to evaluate phytochemicals and antioxidant activity of wild plants. Food Chemistry, 127(4): 1600-1608, 2011.

4. Choi, C. W., Kim, S. C., Hwang, S. S., Choi, B. K., Ahn, H. J., Lee, M. Y., ... \& Kim, S. K. Antioxidant activity and free radical scavenging capacity between Korean medicinal plants and flavonoids by assay-guided comparis on. Plant science, 163(6): 1161-116, 2002.

5. Kähkönen, M. P., Hopia, A. I., Vuorela, H. J., Rauha, J. P., Pihlaja, K., Kujala, T. S., \& Heinonen, M. Antioxidant activity of plant extracts containing phenolic compounds. Journal of agricultural and food chemistry, 47(10): 3954-3962, 1999.

6. Pandey, K. B., \& Rizvi, S. I. Plant polyphenols as dietary antioxidants in human health and dis ease. Oxidative medicine a cellular longevity, 2(5);270-278, 2009.

7. Duthie, G. G., Duthie, S. J., \& Kyle, J. A. Plant polyphenols in cancer and heart disease: implications as nutritional antioxidants. Nutrition research reviews; 13(1): 79-106, 2000. 
8. KIMURA, Y. New anticancer agents: in vitro and in vivo evaluation of the antitumor and anti-metastatic actions of various compounds is olated frommedicinal plants. In Vivo, 19(1):37-60, 2005.

9. Balunas, M. J., \& Kinghorn, A.D. Drug discovery frommedicinal plants. Life sciences, 78(5): 431-441, 2005.

10. Rahman, S., Hasnat, A., Has an, C. M., Rashid, M. A., \& Ilias, M. Pharmacological evaluation of Ban g lade shi medicinal plants — a review. Pharmaceutical biology; 39(1): 1-6, 2001.

11. SvobodováB, Kubáň V. Solanaceae: A family well-known and stillsurprising. BenthamScience Publis hers; 2018 Nov 15.

12. Varandas, R., Egas, C., \& Conceição, I.Luci. Potato cystnematodes: New solutions to an old problem. Crop protection; 137: 105303, 2020.

13. Ferro, E. A., Alvarenga, N. L., Ibarrola, D. A., Hellión-Ibarrola, M. C., \& Ravelo, A. G. A new steroidal saponin fromSolanums is ymbriifolium roots. Fitoterapia; 76(6):577-579, 2005.

14. Weis senberg, M. Is olation of solasodine and other steroidal alkaloids and sapogenin s by direct hydroly sis extraction of Solanum plants or glycosides therefrom. Phytochemistry; 58(3): 501-508, 2001.

15. Chakravarty, A. K., Mukhopadhyay, S., Saha, S., \& Pakrashi, S. C. A neolignan and sterols in fruits of Solanum sisymbri [i] folium (collected from India). Phytochemistry; 41(3): 935-939, 1996

16. Hellión-lbarrola, M. C., Montalbetti, Y., Heinichen, O., Alvarenga, N., Figueredo, A., \& Ferro, E. A. Is olation of hypotensive compounds from Solanum sisymbriifoliumLam. Journal ofethnopharmacology; 70 (3): 301$307,2000$.

17. Barua, R., Sultana, S., Talukder, M. E. U., Chakma, K., Hasan, C. M. M., \& Islam, M. S. Antioxidant and cytotoxic activity of crude flavonoid fraction from the fruits of hybrid variety of Momordica charantia (Bitter gourd). Joumal of Pharmaceutical Research International; 4(7):778-786, 2014.

18. Harborne, J.B., Phytochemical Methods: A Guide to Modern Techniques of Plant Analysis . 2nd edition, Chapman and Hall Publishers, New York; pp: 85, 1973.

19. Edeoga, H.O., Okwu, D.E and Mbaebie, B.O. Phytochemical constituents of some Nigerian medicin al plan ts. Afr. J. Biotechnol; 4(7): 685-688, 2005.

20. Boham,B.A., \& Kocipai-Abyazan, R. Flavonoids and condensed tannins fromleaves of Hawaiian vacciniu m vaticulatumand V. calycinium. Pacific sci; 48: 458-463. 1974.

21. Obadoni, B.O. and Ochuko, P.O. Phytochemical studies and comparative efficacy of the crude extracts of some homeostatic plants in Edo and Delta States of Nigeria. Global J. Pure and Appl. Sci; 8:203-208, 2001

22. Mills, D.F. Symposia fromthe XII International congress on Nutrition Prog. Clin. Biol. Res; 77: 165 - 71, 1981.

23. Ozturk M, Ozturk FA, Duru ME, Topcu G. Antioxidant activity of stemand root extracts of Rhu barb (Rheu m ribes): An edible medicinal plant. Food Chem; 103:623-630, 2007.

24. Marxen K, Vanselow KH, Lippemeier S, Hintze R, Ruser A, Hansen UP. Determination of DPPH radical oxidation caused by methanolic extracts of some microalgal species by linear regression analysis of spectrophotometric measurements. Sensors; 7:2080-2095, 2007.

25. Lee YR, Woo KS, Kim KJ, Son JR, Jeong HS. Antioxidant Activities of Ethanol Extracts from Germinated Specialty Rough Rice. Food Sci Biotechnol; 16:765- 770, 2007.

26. Apak, R., Özyürek, M., Güçlü, K., \& Çapanoğlu, E. Antioxidant activity/capacity measurement. 1. Classification, physicochemical principles, mechanisms, and electron transfer (ET)-based assays. Journal of agricultural andfood chemistry; 64(5): 997-1027, 2016.

27. Gupta, V. K., Simlai, A., Tiwari, M., Bhattacharya, K., \& Roy, A. Phytochemical contents, antimicrobial and antioxidative activities of Solanums is ymbriifolium. Journal of Applied Pharmaceutical Science; 4(3): 75, 2014. 
28. Prakash V, Saxena S, Gupta S, Singh SK. Preliminary phytochemical screening and biological activities of Adina cardifolia. J Microb Biochem Technol. 2015; 7:33-38.

29. Osman ME, Yassen HH, Deng Deng J, Hussein MS. General Phytochemical Screening and Antioxidant Activity of Some Sudanese Medicinal Plants. J Forest Prod Ind. 2014;3:292-295.

30. Zhang, H.F., Yang, X. H., \& Wang, Y. Microwave assisted extraction of secondary metabolites from plants : Current status and future directions. Trends in Food Science \& Technology; 22(12):672-688, 2011.

31. Gorelick, J., \& Bernstein, N. Elicitation: an underutilized tool in the development of medicinal plants as a source of therapeutic secondary metabolites. In Advances in agronomy; 124: 201-230. Academic Pres s, 2014.

32. Mohammedi, Z., \& Atik, F. Impact of solvent extraction type on total polyphenols content and biological activity from Tamarix aphylla (L.) Karst. International journal of Pharma and Bio science; 2(1):609-615, 2011

33. Rice-evans CA, Miller NJ, Bolwell PG, Bramley PM, Pridham JB. The relative antioxidant activities of plantderived poly phenolic flavonoids. Free Radic Res.; 22(4):375-383, 1995.

34. Simlai, A., \& Roy, A. Analysis of and correlation between phytochemical and antimicrobial constituents of Ceriops decandra, a medicinal mangrove plant, from Indian Sundarban estuary. Journal of Medicinal Plants Research;6(32): 4755-4765, 2012.

35. Shulaev, V., Cortes, D., Miller, G., \& Mittler, R. Metabolomics for plant stress response. Physiologia plantarum; 132(2): 199-208, 2008.

36. Reyes, L. F., \& Cisneros-Zevallos, L. Wounding stress increases the phenolic content and antioxidant c a pacity of purple-flesh potatoes (SolanumtuberosumL.). Journal of Agricultural and Food Chemistry; 5 1(18): 52965300, 2003.

37. Pourmorad,F., Hoss einimehr, S. J., \& Shahabimajd, N. Antioxidant activity, phenol and flavonoid contents of some selected Iranian medicinal plants. African journal ofbiotechnology; 5(11): 1142-1145, 2006.

38. Akhila S, Bindu A, Bindu K, Aleykutty N. Comparative evaluation of extracts of Cit rus limon burm peel for antioxidant activity. J. Young Pharmacists, 1(2):136, 2009

39. Bernardi APM, López-Alarcón C, Aspée A, Rech SB, Von Poser GL, Bridi R, Dutrafilho CS, Lissi E. AntioxidantActivity in Southern Brazil Hypericums pecies. J. Chil. Chem. Soc. 53(4):1658-1662, 2008.

40. More, G. K. A review of the ethnopharmacology, phytochemistry and pharmacological relevance of the South African weed Solanum sisymbriifolium Lam. (Solanaceae). Environment, Development and Sustainability;21(1), 37-50, 2019.

41. Kaur S, MichaelH, Arora S, Härkönen PL, Kumar S. The in vitro cytotoxic and apoptotic activity of Triphalaan Indian herbal drug. J Ethnopharmacol;97(1):15-20, 2005. 


\section{Supplement}

Table 1: DPPH free radical scavenging activity of ethanol and petether extracts of unripe and ripe fruits of Solanum

\begin{tabular}{ccc} 
& sisymbriifolium & \\
\hline NAMEOF SAMPLE & $\mathrm{IC}_{50}$ & LogIC $_{50}$ \\
\hline Ascorbic acid & $1.13 \mu \mathrm{g} / \mathrm{ml}$ & 0.0540 \\
$\begin{array}{c}\text { Ethanol extract of Solanum sisymbrifolium } \\
\text { unripe fruits }\end{array}$ & $689.82 \mu \mathrm{g} / \mathrm{ml}$ & 2.84 \\
$\begin{array}{c}\text { Ethanolextract of Solanum sisymbriifolium ripe } \\
\text { fruits }\end{array}$ & $194.40 \mu \mathrm{g} / \mathrm{ml}$ & 2.29 \\
$\begin{array}{c}\text { Pet ether extract of Solanum sisymbriifolium } \\
\text { unripe fruits }\end{array}$ & $1411.23 \mu \mathrm{g} / \mathrm{ml}$ \\
$\begin{array}{c}\text { Pet ether extract of Solanum sisymbriifolium } \\
\text { ripe fruits }\end{array}$ & $436 \mu \mathrm{g} / \mathrm{ml}$ & 3.15 \\
\hline
\end{tabular}

Table 2: $\mathrm{LC}_{50}$ Values of ethanol and pet ether extracts of unripe and ripe fruits of Solanum sisymbriifolium

\begin{tabular}{cc}
\hline NAMEOF SAMPLE & LC $_{50}$ \\
\hline Gallic Acid & $4.40 \mu \mathrm{g} / \mathrm{ml}$ \\
$\begin{array}{c}\text { Ethanol extract of Solanum sisymbrifolium } \\
\text { unripe fruits }\end{array}$ & $230.6559 \mu \mathrm{g} / \mathrm{ml}$ \\
$\begin{array}{c}\text { Ethanol extract of Solanum sisymbrifolium } \\
\text { ripe fruits }\end{array}$ & $456.1021 \mu \mathrm{g} / \mathrm{ml}$ \\
$\begin{array}{c}\text { Pet ether extract of Solanum sisymbriifolium } \\
\text { unripe fruits }\end{array}$ & $314.9227 \mu \mathrm{g} / \mathrm{ml}$ \\
$\begin{array}{c}\text { Pet ether extract of Solanum sisymbriifolium } \\
\text { ripe fruits }\end{array}$ & $1,017.6848 \mu \mathrm{g} / \mathrm{ml}$ \\
\hline
\end{tabular}

